\title{
The Production of Fuel Oil by Conventional Slow Pyrolysis Using Plastic Waste from a Municipal Landfill
}

\author{
Chumsanti Santaweesuk and Adun Janyalertadun
}

\begin{abstract}
This paper presents the study and experimentation of fuel oil production by conventional slow pyrolysis using plastic waste from a municipal landfill. The different proportions of liquid fuel produced from landfill plastic obtained by non-catalyst conventional slow pyrolysis were studied. The landfill plastic was collected from Warinchamrap municipality landfill, in Thailand. The investigation of recycling of model and waste products based on PP, LDPE, HDPE, and mixed plastic were examined using conventional slow pyrolysis and distillation methods. The experimental results show that the reactivity of conventional slow pyrolysis and distillation can be controlled by temperature, time, and energy. The various types of plastic found in the municipal landfill were converted into differing amounts of liquid fuel. PP was converted into 80\% liquid fuel, LDPE $73 \%$ to liquid fuel, HDPE to $70 \%$ liquid fuel, and mixed plastic to 46\% liquid fuel. The distillation liquid fuel included high-quality liquid fuels. The liquid fuels derived from the waste plastic found in the municipal landfill was similar to petroleum diesel oil.
\end{abstract}

Index Terms-Conventional slow pyrolysis, pyrolysis, municipal landfill, waste plastic oil.

\section{INTRODUCTION}

During last few decades, there has been a large increase in the worldwide population, which has coincided with the need of people to adopt improved living conditions that has led to a dramatically increase of the consumption of polymers, mainly in the form of plastic [1]. Plastics are non-biodegradable polymers containing mostly carbon, hydrogen and few other elements. Nowadays the production and consumption of plastics are more than ever because of modern lifestyle and an urgent need for comfort. As a consequence, responsible disposal of plastic waste has created serious social and environmental arguments [2]. Plastics have become essential materials and their applications in the industrial field are continually increasing. During the same timeframe, waste plastics have created a very serious environmental challenge because of the huge quantities and their disposal problems [3] Plastic retail bags are ubiquitous in modern society because they represent a convenient means to transport purchased goods from the supermarket to the home. Plastic bags are plentiful, inexpensive to produce, sturdy yet low weight, and easy to store and transport [4]. A total of 9,000 tons of

Manuscript received July 26, 2016, revised October 21, 2016.

The authors are with the Department of Mechanical Engineering, Ubonratchathani University, Warinchamrab, Ubonratchathani, 34190, Thailand (corresponding author: Adun Janyalertadun. e-mail: chumsunti_2013@yahoo.com, janyalertadun@ @otmail.com). municipal solid waste, within the Warinchamrap municipality, was collected in 2011, which equates to approximately 25 tons per day. Only $20 \%$ of the waste is recyclable while $12.5 \%$ are waste plastic. Most plastic waste is separated into polyethylene (PE) and polypropylene (PP) [5]. Throughout Thailand, a total of 26.77 million tons of solid waste was generated in 2013, which equates to 73,355 tons per day. Although much of this waste is recyclable, only $19 \%$ is recycled with the remaining $81 \%$ eliminated by control dumping in open dumps and landfills, compost generation, incinerators, and open burning. Current waste disposal methods in Thailand are dominated by landfills and open dumps with the proportion of recycled waste being is low. Plastic waste is a big issue in Thailand, because the amount of recycled plastic remains low due to the high investment needs and operating cost [6].

Recycling of plastics already occurs on a wide scale. The most attractive technique of chemical feedstock recycling is pyrolysis. Thermal cracking or thermal pyrolysis involves the degradation of the polymeric materials by heating in the absence of oxygen [7]. The effect of temperature and the type of reactor on the pyrolysis of waste plastics has been studied by different researchers. The produced liquid fuel is attractive because its properties show its potential for use as chemical feedstock or fuel. The waste plastic oil was compared with petroleum products and it was found that it can also be used as fuel in compression ignition engines [2]. Thermal cracking of polyethylene and polypropylene is usually carried out either in high temperatures to produce an olefin mixture $\left(\mathrm{C}_{1}-\mathrm{C}_{4}\right)$ and aromatic compounds including benzene, toluene and xylene or in lower temperatures of $400-500^{\circ} \mathrm{C}$ where three elements are produced: a high-calorific value gas, condensable hydrocarbon oil, and waxes [1], [8]. Cracking in lower temperatures leaves a waxy product in the reactor that mainly consists of paraffin together with a carbonized char. The gaseous fraction can be used for the supply of the energy required for the pyrolysis after burning. The liquid element mainly consists of linear olefins and paraffin with $\mathrm{C}_{11}-\mathrm{C}_{14}$ carbon atoms with only traces of aromatic compounds [8]. The two types of pyrolysis are slow and fast pyrolysis. In slow pyrolysis, the residence time of vapor in the pyrolysis zone is in the order of minutes or longer. This process is broken down into two types being carbonization and conventional. In fast pyrolysis, the vapor residence time is on the order of seconds or milliseconds. This type of pyrolysis is flash and ultra-rapid [9]. Pyrolysis and catalytic reforming of municipal plastic waste, which comprise of PE, PP, and PS as impurities in municipal plastic waste were also significant. The impurities were acidic and toxic and led to easy deactivation of the catalyst in the case of the conversion of municipal plastic 
waste, which have been compared with the thermal degradation products from municipal plastic waste and model mixed plastics [10]. Recycling via pyrolysis is one of the promising methods for recycling waste plastics and involves thermochemical decomposition of organic and synthetic materials at elevated temperatures in the absence of oxygen to produce fuels. The process is usually conducted at higher temperatures between $500-800^{\circ} \mathrm{C}$. These pyrolytic products can be divided into a liquid component, a gaseous component and solid residues [11].

Pyrolysis is the thermochemical decomposition of organic material at high temperatures. This process is a part of de-polymerization, which is in contrast to the creation of plastics which uses polymerization from syngas and crude oil. After the process of pyrolysis, wax and carbon black were created. Liquid fuel created from pyrolysis has similar properties to generic diesel oil and benzene oil. In the present investigation, the recycling of model and waste products based on PP, LDPE, HDPE, and mixed plastic was examined using pyrolysis and distillation methods. This study identifies different proportions of liquid fuel from landfill plastic obtained by non-catalyst conventional slow pyrolysis. The landfill plastic was collected from Warinchamrap municipality landfill, in Thailand.

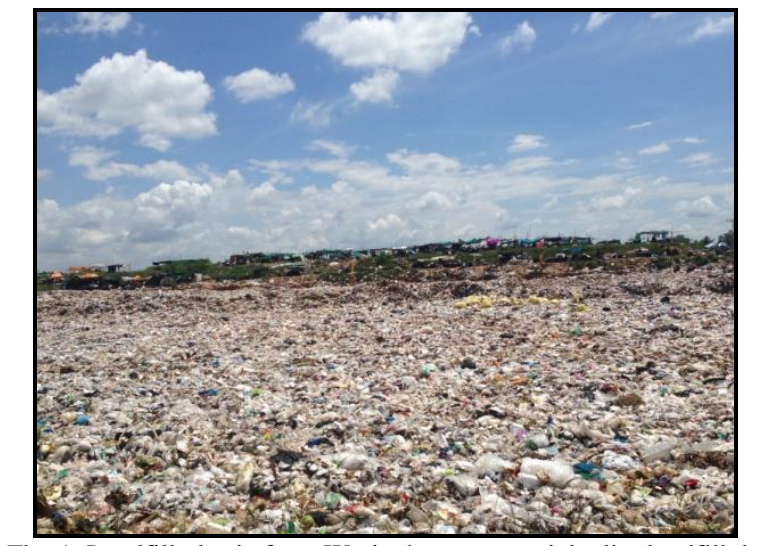

Fig. 1. Landfill plastic from Warinchamrap municipality landfill, in Thailand.

\section{EXPERIMENTATION AND METHODOLOGY}

The landfill plastic was collected from Warinchamrap municipality landfill, in Thailand (Fig. 1 was the main component used in this study. The compositions of waste plastic from Warinchamrap municipality landfill are grouped into polyethylene (PE), and polypropylene (PP), which have $20 \%$ of dirty contaminated contents.

1) Production pyrolysis of municipal landfill plastic waste to produce pyrolysis liquid fuel (PLF)

The pyrolysis process involves the brake down of large molecules to smaller molecules. The thermochemical conversions of landfill plastic to crude landfill plastic oil were conducted using a pyrolysis batch reactor. Pyrolysis was performed in a pyrolysis plant plastic-to-oil system containing a 30 L reactor and oil collection system using approximately 5 $\mathrm{kg}$ of landfill plastic each time. The pyrolysis plant that was used to produce pyrolysis liquid fuel (PLF) is shown in Fig. 2. The pyrolysis plant is operated using a rotary kiln reactor with a non-catalyst. The landfill plastics were fed into and burnt in the reactor. Briefly, these landfill plastics are heated up to $350-450^{\circ} \mathrm{C}$ by using an LPG burner at atmospheric pressure. The temperature is then maintained for about 4-6 hours (the retention time) at $350-450{ }^{\circ} \mathrm{C}$ for. 5 to $10^{\circ} \mathrm{C}$ increments are introduced to make the plastics change gradually. In a typical run, the reactor is heated without oxygen. The gaseous products are condensed to liquid oil in a condenser tank at $25-30^{\circ} \mathrm{C}$. When the liquid has cooled down, it reforms to the pyrolysis liquid fuel (PLF). The PLF yield from pyrolysis of landfill plastic is shown Fig. 3. The pyrolysis process involves the brake down of large molecules to smaller molecules. Produced hydrocarbon with a small molecular mass can be separated by fractional distillation and then used as fuel and chemicals. The condensed products were measured and the yield of liquid products was determined by dividing the collected material by the weight of fed plastics.

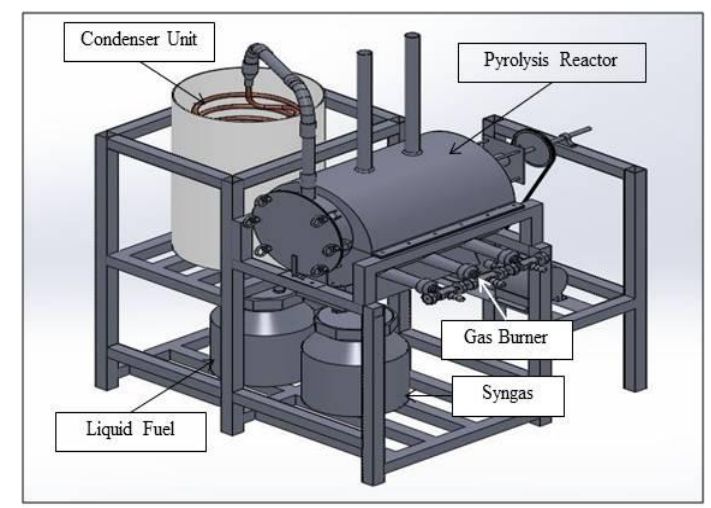

Fig. 2. Schematic diagram of Pyrolysis pant.

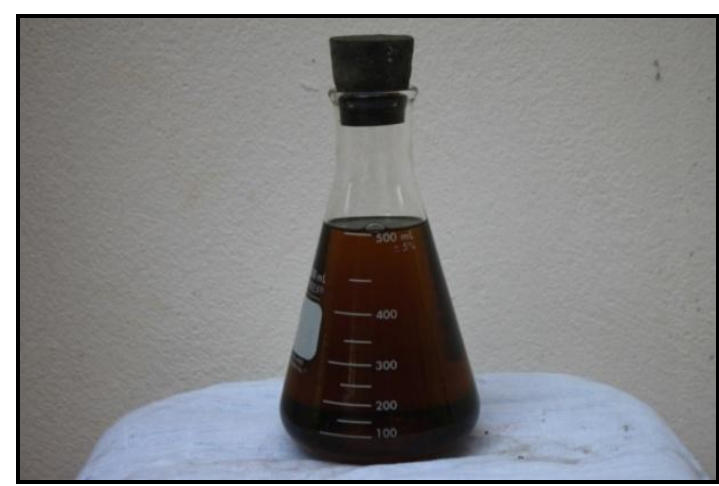

Fig. 3. Pyrolysis liquid fuel (PLF).

2) Production distillation of pyrolysis liquid fuel (PLF) to distillation liquid fuel (DLF)

Fig. 4 shows the schematic diagram of separated distillation system. Distillation of pyrolysis liquid fuel (PLF) to distillation liquid fuel (DLF) was performed in a separated distillation system. The refineries are a separate process based on temperature. $10 \mathrm{~L}$ of pyrolysis liquid fuel (PLF) was added to the separated distillation reactor vessel. The oil collection tank was cleaned by removing the water and dried before starting distillation. For collecting the distillation liquid fuel 1 (DLF1) gasoline equivalent fraction $\left(<170^{\circ} \mathrm{C}\right)$, the upper and lower temperatures were set to 170 and $180^{\circ} \mathrm{C}$, respectively. The upper zone temperature was then raised to $260^{\circ} \mathrm{C}$ and lower zone to $250^{\circ} \mathrm{C}$ to collect a distillation liquid fuel 2 (DLF2) jet equivalent fraction $\left(170-250^{\circ} \mathrm{C}\right)$. The distillation liquid fuel 3 (DLF3) diesel equivalent fraction $\left(250-350^{\circ} \mathrm{C}\right)$ was then collected by setting the upper zone temperature to 
$350^{\circ} \mathrm{C}$ and lower zone to $260^{\circ} \mathrm{C}$. The product yield from pyrolysis liquid fuel (PLF) to distillation liquid fuel (DLF) is shown in Fig. 5. The condensed products were measured and the yields of liquid products were determined by dividing the collected material by the volume of the pyrolysis liquid fuel (PLF). The distillation liquid fuel (DLF) is shown in Fig. 5. The liquid products have been classified into three groups, the gasoline fraction $\left(\mathrm{C}_{5}-\mathrm{C}_{12}\right)$, diesel fuel fraction $\left(\mathrm{C}_{13}-\mathrm{C}_{20}\right)$, and heavy oil $\left(>\mathrm{C}_{20}\right)$ [12], [13]. The liquid products from plastic waste could thus be considered as a mixture of heavy naphtha $\left(\mathrm{C}_{7}-\mathrm{C}_{10}\right)$, gasoline $\left(\mathrm{C}_{8}-\mathrm{C}_{10}\right)$, and light gas oil $\left(\mathrm{C}_{10}-\mathrm{C}_{20}\right)$. The gaseous products typically contain $\mathrm{C}_{1}-\mathrm{C}_{4}$ paraffin hydrocarbons with some olefins [12].

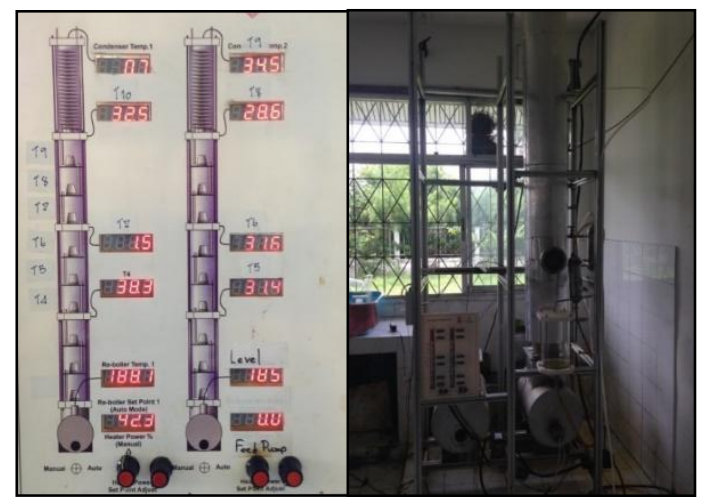

Fig. 4. Schematic diagram of separated distillation system.

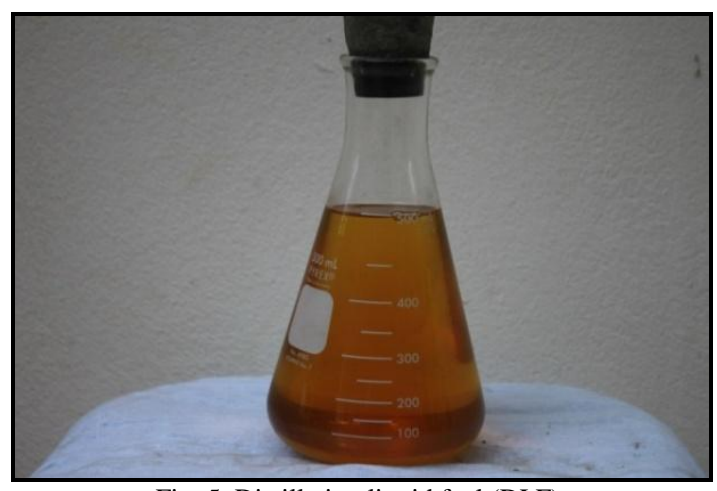

Fig. 5. Distillation liquid fuel (DLF).

\section{RESULTS AND DISCUSSION}

The study of the production of liquid fuel oil from landfill plastic waste was the design and creation of a pyrolysis pant production cycle, regardless of the temperature, time and volume of production.

1) Ratio of pyrolysis liquid fuel (PLF)

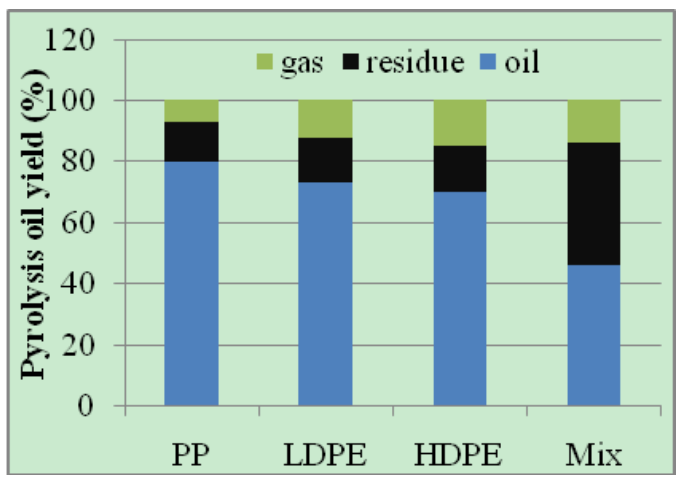

Fig. 6. The ratio of pyrolysis liquid fuel from municipal landfill plastic PP, LDPE, HDPE and Mix plastics.
The pyrolysis process must take into account the temperature and time to create a reaction. A relationship between temperature and time is required. The pyrolysis process has slow and fast parts. The slow pyrolysis can also be split into conventional form and carbonization. The ratio of pyrolysis liquid fuel from the municipal landfill plastics (PP, LDPE, HDPE and mixed plastic) is shows in Fig. 6. The PP rate of change into a pyrolysis liquid fuel (PLF) was $80 \%$ by weight of the ash residue, $13 \%$ by weight of non-condensable gas, and another $7 \%$ waste. For LDPE, the rate of change into a pyrolysis liquid fuel (PLF) was $73 \%$ by weight of the ash residue, $15 \%$ by weight, and $12 \%$ non-condensing gases. For HDPE, the rate of change into a pyrolysis liquid fuel (PLF) was $70 \%$ by weight of the ash residue, $15 \%$ by weight, and $15 \%$ non-condensing gases. egnahc fo etar ehT of mixed plastic was into pyrolysis liquid fuel (PLF) was $46 \%$ by weight of the residue ash, $40 \%$ by weight, and $14 \%$ non-condensing gases. In this the study we used a conventional slow pyrolysis process, with the temperature being $250-350^{\circ} \mathrm{C}$ to create the reaction. This study shows, when the temperature increases the yield of liquid products having low boiling points and gas products increases. The reason for this is during the oxidation degradation process, oxygen from air bonded to the organic compounds and this caused the formation of peroxides first. In this reaction series, the oxygen committed to the organic compounds at the end of the reactions produced the high liquid yield [14].

2) Distillation temperature of pyrolysis liquid fuel (PLF)

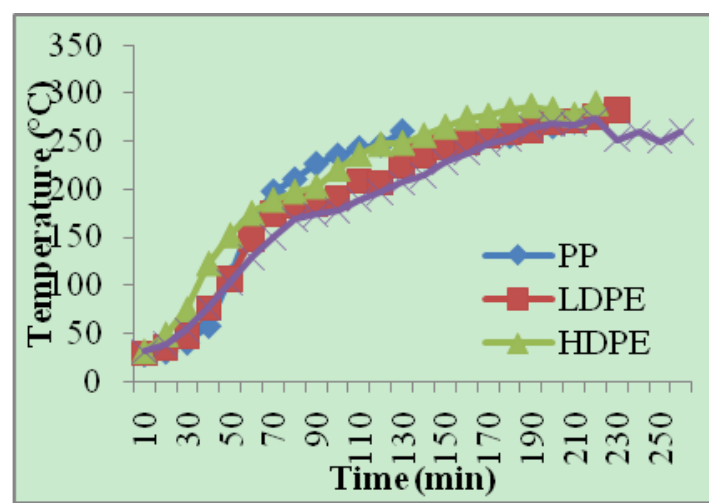

Fig. 7. The distillation temperature of pyrolysis liquid fuels from municipal landfill plastic PP, LDPE, HDPE and Mix plastics.

The distillation temperatures of pyrolysis liquid fuels from municipal landfill plastic (PP, LDPE, HDPE and mixed plastic) is shown in Fig. 7. It can be seen that the reaction temperatures of the plastic vary up to $300^{\circ} \mathrm{C}$, and that these are the temperatures that the plastic types change from a solid state to liquid and vapor. The plastic types have different temperature ranges. PP has an average reaction temperature of $195^{\circ} \mathrm{C}$. LDPE has an average reaction temperature of $192^{\circ} \mathrm{C}$. HDPE has an average reaction temperature of $207^{\circ} \mathrm{C}$. And mixed plastic has an average reaction temperature of $191^{\circ} \mathrm{C}$. The plastic types used different timeframes for their reaction, which is equally significant. PP took 210 minutes to react. LDPE took 230 minutes to react. HDPE took 220 minutes to react. And the mixed plastic reaction time was 260 minutes. The differing temperatures that resulted in decomposition reactions provided hydrocarbons of different chain lengths. Pyrolysis of waste plastic grocery bags at 
temperatures of $420-440^{\circ} \mathrm{C}$ obtained a $74 \%$ yield of liquid product, referred to as plastic crude oil [4].

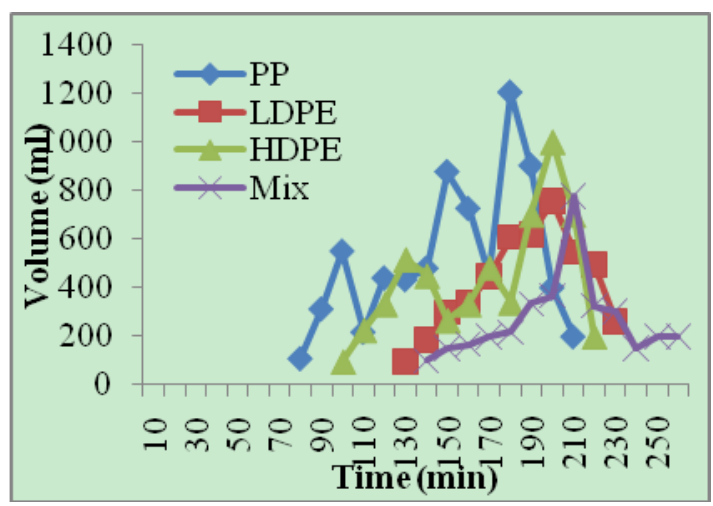

Fig. 8. The volume distillation of pyrolysis liquid fuels from municipal landfill plastic PP, LDPE, HDPE and Mix plastics.

The distillation volume of pyrolysis liquid fuels from municipal landfill plastic is shown in Fig. 8. The volume of liquid fuels made from pyrolysis from municipal landfill plastic is varied. The volume of liquid fuel from PP is 4,820 $\mathrm{ml}$, or $80 \%$ by weight. The volume of liquid fuels from LDPE is $4,400 \mathrm{ml}$, about $73 \%$ by weight. The volume of liquid fuel from HDPE is $4,150 \mathrm{ml}$, or $70 \%$ by weight. And the volume of liquid fuel from mixed plastic is $2,700 \mathrm{ml}$. or $46 \%$ by weight. The volume was also correlated with temperature and reaction time. Thermal cracking of these products could have been achieved by increasing pyrolysis temperature and time, which we speculate would have resulted in higher yields of the desired plastic crude oil fraction [4]. The influences of various conditions on the yield of the liquids were determined. It is well known that the thermal cracking of the plastics takes place by radical mechanism when the reaction is commenced by thermally generated radicals [14].

3) 3.3 Ratio of distillation liquid fuel (DLF)

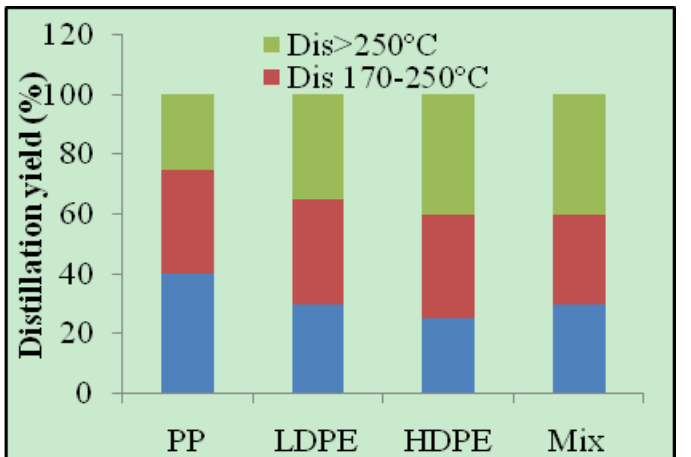

Fig. 9. The amount of liquid fuel derived from the distillation of the various temperature ranges of plastic PP, LDPE, HDPE and Mix plastics.

The amount of liquid fuel derived from the distillation of the various temperature ranges of PP, LDPE, HDPE, and mixed plastics is shown in Fig. 9. It can be seen that the different temperatures determine the volume of the liquid fuel yield. For PP, when the distillation temperature was below $170^{\circ} \mathrm{C}$, the liquid fuel yield was $40 \%$, a distillation temperature of $170-250^{\circ} \mathrm{C}$ yielded $35 \%$ liquid fuel, and when the distillation temperature was higher than $250^{\circ} \mathrm{C}$ the liquid fuel yield was $25 \%$ by volume. LDPE at a distillation temperature range below $170^{\circ} \mathrm{C}$ yielded $30 \%$ liquid fuel, with a distillation temperature of $170-250^{\circ} \mathrm{C}$ the yield of liquid fuel was $35 \%$, and with a distillation temperature higher than $250^{\circ} \mathrm{C}$ the liquid fuel yield was $35 \%$ by volume. HDPE at a distillation temperature below $170^{\circ} \mathrm{C}$ yielded $25 \%$ of liquid fuel, whereas, with a distillation temperature of $170-250^{\circ} \mathrm{C}$ the yield of liquid fuel was $35 \%$, and with a distillation temperature higher than $250^{\circ} \mathrm{C}$ the yield of liquid fuel was $40 \%$ by volume. Mixed plastic at a distillation temperature below $170^{\circ} \mathrm{C}$ yielded $30 \%$ of liquid fuel, when the distillation temperature was $170-250^{\circ} \mathrm{C}$ the yield of liquid fuel was $30 \%$, and when the distillation temperature was higher than $250^{\circ} \mathrm{C}$ the liquid fuel yield was $40 \%$ by volume. The liquid products from plastic waste could thus be considered as a mixture of heavy naphtha $\left(\mathrm{C}_{7}-\mathrm{C}_{10}\right)$, gasoline $\left(\mathrm{C}_{8}-\mathrm{C}_{10}\right)$ and light gas oil $\left(\mathrm{C}_{10}-\mathrm{C}_{20}\right)$ fractions. The gaseous products typically contain $\mathrm{C}_{1}-\mathrm{C}_{4}$ paraffin hydrocarbons with some olefins [12].

TABLE I: THE PROPERTIES OF LIQUID FUEL FROM PLASTIC WASTE COMPARED TO PETROLEUM DiESEL FuEL

\begin{tabular}{lccccc}
\hline \hline Type Fuel & Diesel & PP & LDPE & HDPE & Mixed \\
\hline Gross calorific value & 45.5 & 40 & 41.5 & 42.5 & 42 \\
\hline Kinematic viscosity & 3.162 & 1.970 & 2.310 & 2.420 & 2.630 \\
\hline Specific Gravity & 0.834 & 0.750 & 0.780 & 0.800 & 0.800 \\
\hline Cetane index & 64 & 40 & 40 & 51 & 55 \\
\hline Flash point & 75 & $<25$ & $<25$ & 40 & 50 \\
\hline Distillation temperature & 250 & 100 & 100 & 100 & 100 \\
\hline Distillation temperature & 300 & 160 & 175 & 210 & 220 \\
\hline Distillation temperature & 350 & 270 & 285 & 320 & 335 \\
\hline \hline
\end{tabular}

TABLE II: THE PROPERTIES OF LIQUID FUEL FROM PLASTIC WASTE COMPARED TO PETROLEUM DIESEL FUEL

\begin{tabular}{lcccc}
\hline \hline Type Fuel & Diesel & $<170$ & $170-250$ & $>250$ \\
\hline Gross calorific value & 45.5 & 37 & 40 & 46 \\
\hline Kinematic viscosity & 3.162 & 1.732 & 1.810 & 2.085 \\
\hline Specific Gravity & 0.834 & 0.735 & 0.780 & 0.800 \\
\hline Cetane index & 64 & 35 & 59 & 75 \\
\hline Flash point & 75 & $<25$ & 50 & 60 \\
\hline Distillation temperature & 250 & 100 & 170 & 245 \\
\hline Distillation temperature & 300 & 130 & 200 & 280 \\
\hline Distillation temperature & 350 & 162 & 243 & 320 \\
\hline \hline
\end{tabular}

The liquid fuel from plastic waste has been found to have comparable properties to petroleum fuel, especially when applied to liquid fuels from plastic and then refining the product by distillation. The condensation temperature is the separation of light, medium and heavy oil, which is comparable to petroleum diesel fuel. Table I and II show the properties of liquid fuel from plastic waste compared to petroleum diesel fuel. The gross calorific value according to ASTM D240 standard diesel fuel is $45.50 \mathrm{MJ} / \mathrm{kg}$ of liquid fuel, whereas from PP it is $40 \mathrm{MJ} / \mathrm{kg}$ of liquid fuel, from LDPE it is $41.50 \mathrm{MJ} / \mathrm{kg}$ of liquid fuel, from HDPE is $42.50 \mathrm{MJ} / \mathrm{kg}$ of liquid fuel, and from mixed plastic it is $42 \mathrm{MJ} / \mathrm{kg}$ of liquid fuel. Where the distillation temperature is below $170^{\circ} \mathrm{C}$ the gross calorific value is $37 \mathrm{MJ} / \mathrm{kg}$ of liquid fuel. When the distillation temperature is $170-250^{\circ} \mathrm{C}$ it is $40 \mathrm{MJ} / \mathrm{kg}$ of liquid fuel. And with a distillation temperature higher than $250^{\circ} \mathrm{C}$ the gross calorific value is $46 \mathrm{MJ} / \mathrm{kg}$ of liquid fuel. Waste plastic grocery bags have an empirical formula of $\mathrm{CH}_{2}$, which 
is quite similar to that of polyethylene. Higher carbon and hydrogen content and lower oxygen and nitrogen content resulted in a higher calculated calorific value for most of the plastic types, making this high energy liquid fuel [4]. Kinematic viscosity @ $40^{\circ} \mathrm{C}$ according to ASTM D445 for diesel fuel is $3.162 \mathrm{cst}$. Liquid fuel from PP is $1.970 \mathrm{cst}$, liquid fuel from LDPE is $2.310 \mathrm{cst}$, liquid fuel from HDPE is 2.420 cst, and liquid fuel from mixed plastic is $2.630 \mathrm{cst}$. Liquid fuel produced during a distillation temperature below $170^{\circ} \mathrm{C}$ is $1.732 \mathrm{cst}$, liquid fuel produced during a distillation temperature of $170-250^{\circ} \mathrm{C}$ is $1.810 \mathrm{cst}$, and liquid fuels produced during a distillation temperature higher than $250^{\circ} \mathrm{C}$ is 2.085 cst. The specific gravity@ $15.6^{\circ} \mathrm{C}$ according to ASTM D1298 diesel fuel is 0.834 . The liquid fuel from PP is 0.750 , the liquid fuels from LDPE0 is 0.780 , the liquid fuels from HDPE is 0.800 , and the liquid fuels from mixed plastic is 0.800 . Liquid fuels produced at a distillation temperature below $170^{\circ} \mathrm{C}$ is 0.735 , liquid fuels produced at a distillation temperature of $170-250^{\circ} \mathrm{C}$ is 0.780 , and liquid fuels produced at a distillation temperature higher than $250^{\circ} \mathrm{C}$ is 0.800 . The calculated cetane index according to ASTM D976 diesel fuel is 64. Liquid fuel from PP is 40, liquid fuel from LDPE is 40, liquid fuel from HDPE is 51, and liquid fuel from mixed plastic is 55. Liquid fuel produced with a distillation temperature below $170{ }^{\circ} \mathrm{C}$ is 35 , liquid fuel produced at a distillation temperature range of $170-250^{\circ} \mathrm{C}$ is 59 , and liquid fuels produced at a distillation temperature higher than $250^{\circ} \mathrm{C}$ is 75. The Flash point, according to ASTM D93 diesel fuel is $75^{\circ} \mathrm{C}$, liquid fuel from $\mathrm{PP}$ is $\angle 25^{\circ} \mathrm{C}$, liquid fuel from LDPE is $<25^{\circ} \mathrm{C}$, liquid fuel from HDPE is $40^{\circ} \mathrm{C}$, and liquid fuel from mixed plastic is $50^{\circ} \mathrm{C}$. Liquid fuel produced at a distillation temperature below $170^{\circ} \mathrm{C}$ is $\angle 25^{\circ} \mathrm{C}$, liquid fuel produced at a distillation temperature range of $170-250^{\circ} \mathrm{C}$ is $50^{\circ} \mathrm{C}$, and liquid fuel produced at a distillation temperature higher than $250^{\circ} \mathrm{C}$ is $60^{\circ} \mathrm{C}$. Distillation temperature @ $10 \%, 50 \%$ and $90 \%$ according to ASTM D86 diesel fuel is $270,300,350^{\circ} \mathrm{C}$ respectively. Liquid fuels from $\mathrm{PP}$ is $100,160,270^{\circ} \mathrm{C}$ respectively, liquid fuel from LDPE is $100,175,285^{\circ} \mathrm{C}$ respectively, liquid fuels from $\mathrm{HDPE}$ is $100,210,320^{\circ} \mathrm{C}$ respectively, and liquid fuel from mixed plastic is 100,220 , $335^{\circ} \mathrm{C}$ respectively. Liquid fuel produced at a refining temperature range lower than $170^{\circ} \mathrm{C}$ is $100,130,162^{\circ} \mathrm{C}$, liquid fuel produced at a refining temperature range condensation of $170-250^{\circ} \mathrm{C}$ is $170,200,243^{\circ} \mathrm{C}$ respectively and liquid fuels produced at a higher than $250^{\circ} \mathrm{C}$ temperature condensation range is $245,280,320^{\circ} \mathrm{C}$ respectively. The quality of pyrolysis liquid fuel (PLF) was still lower than those of commercial diesel fuels according to the oil properties. Distillation liquid fuel (DLF) of waste plastic oil will obtain better quality oil. Municipal plastic waste pyrolysis produced higher heating values than solid products such as biomass and low rank coal, so they can be used either for blending with biomass and coal or as a single fuel [13]. Liquid hydrocarbons, with appropriate boiling ranges, produced from pyrolysis of waste plastic, appear suitable as blend components for conventional petroleum diesel fuel [4]. The usefulness and feasibility of the pyrolysis process of mixed plastics as an alternative approach to feedstock recycling is established [15]. Waste plastic oil is a mixture of $\mathrm{C}_{10}$ to $\mathrm{C}_{30}$ organic compounds. An internal combustion engine was able to run on $100 \%$ waste plastic oil. The engine fueled with waste plastic oil exhibits higher thermal efficiency up to $75 \%$ of the rated power [16]. Thermal cracking converts the plastic pyrolysis heavy oils into light liquid fractions which are only composed of alkanes and aromatics [17].

\section{CONCLUSIONS}

This study reviewed different proportions of liquid fuel produced from landfill plastic obtained by non-catalyst conventional slow pyrolysis. The landfill plastic was collected from waste products based on PP, LDPE, HDPE, and mixed plastic and was examined using conventional slow pyrolysis and distillation methods. The experimental results have shown that conventional slow pyrolysis and distillation can be used to control the temperature, time and energy to be less reactive.

The various types of plastic produced different amounts of liquid fuels. PP produced $80 \%$ liquid fuel, LDPE produced $73 \%$ liquid fuel, HDPE produced $70 \%$ liquid fuel, and mixed plastic produced $46 \%$ liquid fuel.

The distillation liquid fuel is made up of high-quality liquid fuels. A distillation temperature of PP below $170^{\circ} \mathrm{C}$ yielded $40 \%$ liquid fuel, a distillation temperature of $170-250^{\circ} \mathrm{C}$ yielded $35 \%$ of liquid fuel, and a distillation temperature higher than $250{ }^{\circ} \mathrm{C}$ yielded $25 \%$ liquid fuel by volume. LDPE yielded liquid fuel at $30 \%, 35 \%$, and $35 \%$ by volume, HDPE yielded $25 \%, 35 \%$, and $40 \%$ by volume, and mixed plastic yielded $30 \%, 30 \%$, and $40 \%$ by volume.

The fuel properties of liquid fuels derived from municipal landfill plastic waste were similar to petroleum diesel oil. The feedstock types affect the product yields, and the quality of pyrolysis liquid fuel (PLF) and distillation liquid fuel (DLF).

\section{ACKNOWLEDGEMENTS}

The author thanks the Energy Policy \& Planning Office (EPPO), Ministry of Energy, Thailand, for the Ph.D. course financial grant; and also thanks the Department of Mechanical Engineering, Ubonratchathani University and Khonkaen University, Thailand, for the experimental fuel oil.

\section{REFERENCES}

[1] D. S. Achilias et al., "Chemical recycling of plastic wastes made from polyethylene (LDPE and HDPE) and polypropylene (PP)," Journal of Hazardous Materials, vol. 149, pp. 536-542, 2007.

[2] J. Scheirs and W. Kaminsky, Feedstock Recycling and Pyrolysis of Waste Plastics: Converting Waste Plastics into Diesel and Other Fuels, John Wiley \& Sons, Hoboken, 2006.

[3] S. Kumar et al., "Performance and emission analysis of blends of waste plastic oil obtained by catalytic pyrolysis of waste HDPE with diesel in a CI engine," Energy Conversion and Management, vol. 74, pp. 323-331, 2013.

[4] B. K. Sharma et al., "Production, characterization and fuel properties of alternative diesel fuel from pyrolysis of waste plastic grocery bags," Fuel Processing Technology, vol. 122, pp. 79-90, 2014.

[5] R. Tubnonghee, Workshop on Capacity Building on Accounting and Utilizing GHG Emission Reduction Measures for Local Waste Management Actors in Thailand, Bangkok, Thailand, 2012.

[6] Pollution Control Department, Report Situation Wastes of Thailand 2013, Ministry of Natural Resources and Environment, Thailand, 2014.

[7] S. Kumar and R. K. Singh, "Recovery of hydrocarbon liquid from waste high density polyethylene by thermal pyrolysis," Braz J. Chem Eng., vol. 28, no. 04, pp. 659-67, 2011.

[8] J. Aguado and D. P. Serrano, Feedstock Recycling of Plastic Wastes The Royal Society of Chemistry, Cambridge, 1999. 
[8] J. Aguado and D. P. Serrano, Feedstock Recycling of Plastic Wastes, The Royal Society of Chemistry, Cambridge, 1999.

[9] P. Basu, Biomass Gasification and Pyrolysis, Elsevier, United States, 2010.

[10] J. L. Wang and L. L. Wang, "Catalytic pyrolysis of municipal plastic waste to fuel with nickel-loaded silica-alumina catalysts," Energy Sources, Part A: Recovery, Utilization, and Environmental Effects, 2011, vol. 33, pp. 1940-1948.

[11] J. Aguado et al., "Feedstock recycling of polyethylene in a two-step thermo-catalytic reaction system," Journal of Analytical and Applied Pyrolysis, vol. 79, pp. 415-423, 2007.

[12] A. Demirbas, "Pyrolysis of municipal plastic wastes for recovery of gasoline-range hydrocarbons," Journal of Analytical and Applied Pyrolysis, vol. 72, pp. 97-102, 2004.

[13] M. Syamsiro et al., "Fuel oil production from municipal plastic wastes in sequential pyrolysis and catalytic reforming reactors," in Proc. Conference and Exhibition Indonesia Renewable Energy \& Energy Conservation, pp. 180-188, 2014.

[14] A. Koca and A. Y. Bilgesub, "Catalytic and thermal oxidative pyrolysis of LDPE in a continuous reactor system," Journal of Analytical and Applied Pyrolysis, vol. 78, pp. 7-13, 2007.

[15] M. N. Siddiqui and H. H. Redhwi, "Pyrolysis of mixed plastics for the recovery of useful products," Fuel Processing Technology, vol. 90, pp. 545-552, 2009.

[16] M. Mani et al., "Performance, emission and combustion characteristics of a DI diesel engine using waste plastic oil," Applied Thermal Engineering, vol. 29, pp. 2738-2744, 2009.

[17] A. L. Urionabarrenechea et al., "Upgrading of chlorinated oils coming from pyrolysis of plastic waste," Fuel Processing Technology, vol. 137 pp. 229-239, 2015.

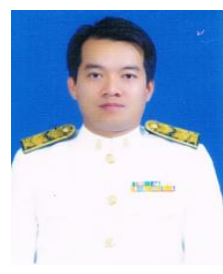

Chumsanti Santaweesuk was born on June 1, 1976 $\mathrm{He}$ got the degree mechanical engineering, majoring in mechanical engineering from the Department of Mechanical Engineering, Faculty of Engineering, Ubon Ratchathani University, Ubonratchathani, Thailand. He is a Ph.D. student majoring in mechanical engineering, Ubon Ratchathani University, Thailand, and is working in Ubonratchathani technical college, Thailand.
He lists military and work experience, including summer and fellowship jobs. This is Santaweesuk C., Janyalertadun A., Techarungpaisan P., Physic nut oil and Performance of Diesel Engine, Proceedings of the $1^{\text {st }}$ Conference of the Renewable Energy Network of Thailand, May $11^{\text {th }}-13^{\text {th }}, 2005$, Chonburi, Thailand, The physical properties of Physic nut oil and performance of diesel engine using Physic nut oil as a fuel, Proceedings of the $19^{\text {rd }}$ Conference of the Mechanical Engineering Network of Thailand, October $19^{\text {th }}-21^{\text {st }}, 2005$, Puket, Thailand, Results of ratio methanol pre biodiesel production from physic nut oil, Proceedings of the $20^{\text {th }}$ Conference of the Mechanical Engineering Network of Thailand, October $18^{\text {th }}-20^{\text {th }}, 2006$, Nakonratchaseema, Thailand, The physical properties of physic nut oil and performance of diesel engine using physic nut oil as a fuel, Published by KKU Engineering Journal Vol. 33 No .6 (613 - 624) November - December 2006.

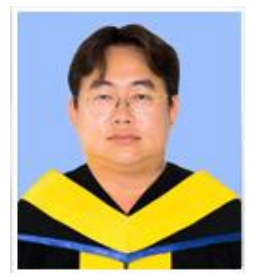

Adun Janyalertadun was born on February 22, 1974. He got the doctor of philosophy in mechanical engineering from University of Hertfordshire, England. $\mathrm{He}$ is an assistant professor in the Department of Mechanical engineering, Faculty of Engineering, Ubonratchathani University, Thailand. His researches are focused on energy and environmental engineering. Now is the vice president of physical and environmental management of Ubonratchathani University. 